\title{
Relationship between Plant Species Diversity and Plant Biomass of Orchard Grass and Lucerne Sown in Different Ratios in the Province of Salamanca, Spain
}

\author{
M. Medina-Sierra1', M. Igual-Arroyo², F. Restrepo-Betancur ${ }^{3}$, A. Valverde-Portal', I. Santa-Regina ${ }^{2}$ \\ ${ }^{1}$ Universidad de Antioquia UdeA, Facultad de Ciencias Agrarias, Escuela de Producción Agropecuaria, Group GRICA (Grupo de \\ Investigación en Ciencias Agrarias), Medellín, Colombia \\ ${ }^{2}$ Instituto de Recursos Naturales y Agrobiología de Salamanca, Consejo Superior de Investigaciones Científicas (IRNASA-CSIC), \\ Salamanca, Spain \\ ${ }^{3}$ Universidad de Antioquia UdeA, Facultad de Ciencias Agrarias, Escuela de Producción Agropecuaria, Group GISER (Grupo de \\ Investigación en Extensión Rural), Medellín, Colombia \\ ${ }^{4}$ Centre for Microbial Ecology and Genomics (CMEG), Department of Genetics, University of Pretoria, Pretoria, South Africa \\ Email: ignacio.santaregina@irnasa.csic.es
}

How to cite this paper: Medina-Sierra, M., Igual-Arroyo, M., Restrepo-Betancur, F., Valverde-Portal, A., \& Santa-Regina, I. (2017). Relationship between Plant Species Diversity and Plant Biomass of Orchard Grass and Lucerne Sown in Different Ratios in the Province of Salamanca, Spain. Open Journal of Forestry, 7, 336-351. https://doi.org/10.4236/ojf.2017.73020

Received: June 7, 2017

Accepted: July 22, 2017

Published: July 25, 2017

Copyright (C) 2017 by authors and Scientific Research Publishing Inc. This work is licensed under the Creative Commons Attribution International License (CC BY 4.0).

http://creativecommons.org/licenses/by/4.0/ (c) (†) Open Access

\begin{abstract}
A field experiment was carried out at the CSIC Muñovela farm belonging to the Spanish National Research Council (CSIC) in order to evaluate the effect of sowing orchard grass (Dactylis glomerata var. Trerano) and lucerne (Medicago sativa var. Aragon) in monoculture and in combination. The experiment was based on a randomized block designed with a factorial arrangement $(5 \times 2)$. Experimental units were 40 plots distributed in four blocks. The phosphorus fertilization $(\mathrm{P})$ factor included two types of conditions: basal fertilization without phosphorus $(-\mathrm{P})$ and basal fertilization with phosphorus $(+\mathrm{P})$, and the vegetation cover factor $(\mathrm{T})$ included five conditions depending on the grass $(\mathrm{G})$ and the legume $(\mathrm{L})$. Above-ground biomass showed statistically significant differences among seasons and years $(P<0.05)$. However, no statistically significant differences treatments were found among various treatments. The presence of the grass species Lolium perenne L. and Poa pratensis $\mathrm{L}$. throughout the three years indicated that both species significantly increased their presence over time regardless of the treatments applied. The analysis performed for the other plant species (those other than grasses and legumes) allowed us to determine that the $\mathrm{T} 1$ and $\mathrm{T} 5$ treatments, which correspond to single species not treated with the application of phosphorus, influenced the presence of $70 \%$ of other species planted. Our specific aim was to explore how changing plant biotic diversity affects productivity under a given
\end{abstract}


set of conditions. We manipulated plant species richness as an experimental factor to determine if productivity would be affected by changes in the ratios of plants sown.

\section{Keywords}

Above-Ground Biomass, Dactylis glomerata, Functional Groups, Grasses, Legumes, Medicago sativa, Plant Species Diversity, Sowing Experiment

\section{Introduction}

Several ecosystem processes, such as primary productivity, nutrient retention, and vegetation dynamics are affected by changes in plant species diversity (Hector et al., 1999; Schläpfer \& Schmid, 1999; Tilman, 1999; Chapin et al., 2000). Experimental data of Tilman et al. (1996), Hooper (1998), Tilman et al. (1997) and Hector et al. (1999) show a positive effect of the number of species on primary productivity and nutrient retention, but sampling effects may complicate the distinction between the effects of species traits and those of species diversity (Huston, 1997).

The earlier results for mesic environments of Gleeson and Tilman (1990), and Osbornová et al. (1990) indicate an increase in total aboveground biomass with grassland succession. This trend is assumed to be related to successional changes in the traits of the dominant plant species. Annuals and perennials plant species differ in characteristics related to nutrient retention and turnover, including size, relative growth rate resulting from specific leaf area and leaf nitrogen content (Garnier et al., 1997), rooting depth, root to shoot ratio, and foliage C/N ratio (Hooper \& Vitousek, 1997). These characteristics can result in the faster growth of annuals as compared to perennials, and hence, greater instantaneous productivity.

There is an opposing trend, towards set-aside policies and the abandonment of agricultural land in some parts of the world, such as North America and Europe (Richards, 1990). Land abandonment provides opportunities to restore ecosystem properties such as biodiversity and biogeochemical cycles. However, recovery of pre-agricultural soil conditions can be very slow about 200 years for soil carbon and nitrogen, (Knops \& Tilman, 2000). The restoration of former species diversity is often constrained by abiotic and biotic conditions, such as eutrophization or seed bank depletion (Bakker \& Berendse, 1999). In the years just after abandonment, unmanaged land may favour nutrient leaching, constitute reservoirs of aggressive weeds damageable to adjacent fields and alter the aesthetics of the landscape.

Williamson (1996) and Vilà \& Weiner (2004) suggest that introduction of new species is recognized as major environmental problems and one of the major threats to biodiversity. The success and impacts of alien species depends on their biological attributes, the environmental characteristics of the invaded ecosystem 
and the biotic interactions with the receptive community. Competition for limiting resources is probably the first interaction the species has with the recipient community when a new plant species is introduced. Interspecific competition is considered as one of the most important processes determining the likelihood of plant invasion (Crawley, 1990). Vilà and Weiner (2004) considered that high competition ability of new plant species has been stated as a key factor promoting successful invasive potential, and competitive exclusion by native plant species seems to be a major force resisting exotic plant invasions (Keane \& Crawley, 2002).

Seligman (1996) argues that most Mediterranean grasslands grow in soils deficient of one or more nutrients, for example, pasture production is poor in areas of low soil phosphorus availability. Although, an increase of legume species in the plant cover may be obtained by the addition of phosphorus (Osman et al., 1991, 1999; Henkin et al., 1998). When there is a nitrogen enrichment (Foster \& Gross, 1998), the high productivity tends to reduce species diversity (Tilman \& Pacala, 1993; Janssens et al., 1998).

The effects of increasing plant diversity often saturate at rather low numbers of species (in average $90 \%$ of the known cases, the productivity of the most diverse treatment is reached with mixtures of 5 species (Roy, 2001); note that these cases may be biased). Since by definition, functional differences are larger between functional groups than between species, functional group diversity has been found to have a larger impact on ecosystem processes than species diversity (Hector et al., 1999; Hooper, 1998; Tilman et al., 1997). In these experiments, plant functional groups have been identified on the basis of species physiology (C3 vs. C4 species, $\mathrm{N}$ fixers vs. non-N fixers, woody vs. non-woody species) or life history (early vs. late season species, annuals vs. perennials). However, in removal studies, plant functional traits were found to have little impact on soil communities (Wardle et al., 1999).

Our specific aim was to explore how changing plant biotic diversity affects productivity under a given set of conditions. We manipulated plant species richness as an experimental factor to determine if productivity would be affected by changes in the ratios of plants sown.

\section{Experimental Methods}

\subsection{Experimental Site Description}

\subsubsection{Typical Vegetation of the Area}

The Muñovela experimental farm is located in the chorological CARPETANOIBERICO-LEONESA province, province of Salamanca. The climax vegetation corresponds to terminal associations of the siliceous Salamantino supra-Mediterranean series of the oak (Genisto hystricis-Querceto rotundifoliae sigmetum). This feature has been modified by human intervention, which together with the existing morphological situations, has generate considerable heterogeneity in the area. 


\subsubsection{Soil}

The soil is a Chromic Luvisol and is located on a hillside with a slope gradient of less than $4 \%$. The soil horizons correspond to Ap - Bt1 - Bt2 - B/C1 (Blanco et al., 1989).

\subsubsection{Weather Conditions}

The region has a continental dry climate. The temperature values during the experimental time frame (2009-2011) were similar to the average temperature of the 1999-2008. But annual precipitations were different, since 2009 was a particularly very dry year $(240 \mathrm{~mm})$, and had lower than average monthly precipitation as compared to 1999-2008 (390 mm), with the exception of a few months. However, in 2010 the annual precipitation $(550 \mathrm{~mm})$ was higher than the previously mentioned years.

\subsection{Design of the Field Experiment}

Experimental plots were established within the agricultural land of the Muñovela experimental farm. Forty plots of $9 \mathrm{~m}^{2}$ were set up. The distance between plots and blocks was $0.6 \mathrm{~m}$ and $1 \mathrm{~m}$ respectively. The orchard grass (Dactylis glomerata var. Trerano) and lucerne (Medicago sativa var. Aragón) were sown in monoculture and in combination.

The experimental design was in randomized blocks with a factorial arrangement $(5 \times 2)$ that was asymmetrical and balanced and had a fixed effect and repeated measures over time. The experimental units consisted of 40 plots distributed into four blocks. The phosphorus fertilization (P) factor included two conditions: basal fertilization without phosphorus $(-\mathrm{P})$ and basal fertilization with phosphorus $(+\mathrm{P})$. The vegetation cover factor $(\mathrm{T})$ included five conditions depending on the grass $(\mathrm{G})$ and legume $(\mathrm{L})$. The different treatments were:

T1: D. glomerata-without phosphorus $(-\mathrm{P})$

T2: D. glomerata: $M$. Sativa $(75: 25)(-\mathrm{P})$

T3: D. glomerata: $M$. Sativa (50:50) (-P)

T4: D. glomerata: $M$. Sativa (25:75) (-P)

T5: M. Sativa (-P)

T6: D. glomerata-with $\mathrm{P}(+\mathrm{P})$

T7: D. glomerata: M. Sativa $(75: 25)(+\mathrm{P})$

T8: D. glomerata: $M$. Sativa (50:50) (+P)

T9: D. glomerata: M. Sativa $(25: 75)(+\mathrm{P})$

T10: M. Sativa $(+\mathrm{P})$

\subsection{Vegetation Analyses}

\subsubsection{Root Sampling}

Nine consecutive samplings were carried out from 2009 to 2011, during April, July and October. These samples were later called spring, summer and autumn samples, respectively. The soils were extracted with a steel cylindrical probe (4.8 $\mathrm{cm}$ internal diameter) that was introduced into ground to a depth of $10 \mathrm{~cm}$ 
depth. Four extractions were performed randomly in each plot. The final soil sample was composed of the four sub-samples, which were combined and homogeneously mixed.

\subsubsection{Biomass Sampling}

The biomass was measured in each plot during the nine consecutive samplings, where $0.25 \mathrm{~m}^{2}$ frames were used for each of the two samples taken. The plants were separated into three functional groups: grasses, legumes and others. They were dried in a forced air oven at $60^{\circ} \mathrm{C}$ for 48 hours. The dry weight of each group of samples was determined.

Inventory of different kind of species:

A framework of $1 \mathrm{~m}^{2}$ was used for taking the inventory of the different plant species present, and the percentage of coverage was directly determined in each of the field plots.

\subsection{Statistical Analyses}

An experimental randomized block design was used, with unbalanced fixed effect. We considered the associated factors with the interactions (treatment/year and treatment/season). The effect of the season was nested in the effect of the year. This model was built using the generalized linear model incorporated into the multivariate analysis of variance (MANOVA) with orthogonal contrasts. The objective was to compare the effect of treatments according to the response variables under study.

Quantitative variables were transformed by the box-cox transformation family. The analysis was supplemented with descriptive statistics for determining the arithmetic mean, standard deviation and variation coefficient according to the determining factors (year, treatment and season). The data were analyzed using the "SAS University" program.

Multiple correspondence analysis (MCA) with indexed ranking, was used to characterize the presence or absence of the different species. This analysis was supplemented by the effect of the seasons and evaluated treatments. Data were analyzed using SPAD 3.5 statistical package.

\section{Experimental Results and Discussion}

No statistical difference was detected between treatments, when the percentage of coverage was between $77.1 \%$ and $81.1 \%(P>0.05)$. But statistical differences were found between seasons $(P<0.05)$ (Table 1$)$ and between years (Table 2$)$.

Different phosphorus fertilization treatments involving two different conditions (basal fertilization without phosphorus $(-\mathrm{P})$ and basal fertilization with phosphorus $(+\mathrm{P})$ ) on different percentages of dactylo (Dactylis glomerata $\mathrm{L}$ ) and lucerne (Medicago sativa L.) plants show statistically significant differences among seasons $(P<0.05)$ (Table 1$)$ and years (Table 2$)$. However, some of the different treatments did not show statistically significant differences among them. 
Table 1. Comparison of above-ground biomass in the three seasons evaluated.

\begin{tabular}{cccccc}
\hline & By seasons & & \multicolumn{3}{c}{ By years } \\
\hline Season & $\begin{array}{c}\text { Above-ground } \\
\text { biomass (\%) }\end{array}$ & Tukey* & Year & $\begin{array}{c}\text { Above-ground } \\
\text { biomass (\%) }\end{array}$ & Tukey* \\
\hline Spring & 82.5 & $\mathrm{c}$ & 1 & 77.4 & $\mathrm{~b}$ \\
Summer & 80.5 & $\mathrm{~b}$ & 2 & 83.2 & $\mathrm{c}$ \\
Autumn & 74.7 & $\mathrm{a}$ & 3 & 77.1 & $\mathrm{a}$ \\
\hline
\end{tabular}

${ }^{\star}$ Different letters indicate statistical difference $(P<0.05)$.

Table 2. Evaluation of above-ground biomass for each experimental year.

\begin{tabular}{|c|c|c|c|}
\hline Treatment and season & Year 1 & Year 2 & Year 3 \\
\hline D. glomerata-without phosphorus (P) & $74.2 \mathrm{ab}$ & $80.2 \mathrm{a}$ & $79.6 \mathrm{ab}$ \\
\hline D. glomerata: M. Sativa (75:25) - without P & $75 \mathrm{ab}$ & $83.9 \mathrm{a}$ & $77.1 \mathrm{ab}$ \\
\hline D. glomerata: M. Sativa (50:50)—without P & $77.5 \mathrm{ab}$ & $83.5 \mathrm{a}$ & $78.3 \mathrm{ab}$ \\
\hline D. glomerata: M. Sativa (25:75) - without P & $80 \mathrm{~b}$ & $86 a$ & $77.5 \mathrm{ab}$ \\
\hline M. Sativa-without P & $78.3 \mathrm{ab}$ & $83.9 \mathrm{a}$ & $74.2 \mathrm{ab}$ \\
\hline D. glomerata-with P & $70.8 \mathrm{a}$ & $80.4 \mathrm{a}$ & $80 \mathrm{~b}$ \\
\hline D. glomerata: M. Sativa (75:25) - with P & $79.1 \mathrm{ab}$ & $85.2 \mathrm{a}$ & $77.9 \mathrm{ab}$ \\
\hline D. glomerata: M. Sativa (50:50) - with P & $78.7 \mathrm{ab}$ & $82.5 \mathrm{a}$ & $75.8 \mathrm{ab}$ \\
\hline D. glomerata: M. Sativa (25:75) — with P & $80 \mathrm{~b}$ & $84.3 \mathrm{a}$ & $77.9 \mathrm{ab}$ \\
\hline M. Sativa-with P & $80 \mathrm{~b}$ & $81.9 \mathrm{a}$ & $72.5 \mathrm{a}$ \\
\hline \multicolumn{4}{|l|}{ Comparison among seasons: } \\
\hline Summer & $71.4 \mathrm{a}$ & $89.2 b$ & $81 \mathrm{c}$ \\
\hline Autumn & $71.5 \mathrm{a}$ & $80 \mathrm{a}$ & $72.4 \mathrm{a}$ \\
\hline Spring & $89.3 \mathrm{~b}$ & $80.4 \mathrm{a}$ & $77.9 \mathrm{~b}$ \\
\hline
\end{tabular}

Teixeira et al. (2015) report that legumes require phosphorus for better development in Mediterranean ecosystems. Our results show this not to be the case, at least in biomass production. Our experimental plots were not weeded, and for that may introduce hidden forms of treatment, such as soil disturbances that may affect soil mineralization and other abiotic and biotic soil processes, which could in turn affect productivity, being in agreement with the results of Wardle (2001). Oliveira et al. (2015) have found that phosphorus fertilization has only small effects on grassland composition an Ultisol at Southern of Brazil, which was evaluated over a period of sixteen years and during different seasons, as well as Henkin et al. (2006) established during a five year study that phosphorus application significantly increased the productivity and the richness of annual legume species in a Mediterranean community.

van Ruijven \& Berendse (2005) and Lanta \& Lepš (2006) published studies executed on smaller spatial scales indicating that sowing also increased productivity, and, on average, plots with high levels of diversity had the highest produc- 
tivity of all the treatments carried out. Thus, in our experiment, high productivity was connected with high diversity species, not with the total diversity of the plant community, supporting the views that biodiversity-functioning relationships are highly species and context dependent (Wardle \& Zackrisson, 2005), or using similar conditions, treatments with other species could increase the biomass production depending on the specific conditions of each area (Hedlund et al., 2003). Possible differences in productivity between sown diversity plots could be attributed to the respective capacity of the treatments to modify the relative proportion of the component species. Thus, biomass increased with increasing dominance of perennials in the community as a consequence of sowing and successional process.

The higher level of productivity found in both cases indicates that the initial diversity of the plots was greatly increased by sowing different species. Plots where more species were sown were those that eventually went on to present higher biomass; however the highest level of productivity was observed during the second year, which may be due to the weather conditions, and was not accompanied by higher levels of diversity. In addition to inherent production capabilities of each species, the evenness of the distribution (the relative proportion of the component species) can have an influence on productivity (Nijs \& Roy, 2000), especially the relative contribution of dominants and codominants.

The two essential resources in productivity may be mineral nutrients and light (Tilman, 1982). Plant species differ in their ability to grow under different phys$\mathrm{ical} /$ chemical conditions that vary spatially, competing for several resources at any given spatial location. The mechanisms for increased competitive exclusion at high productivities are based on the fact that higher productivities will reduce spatial heterogeneity in the relative supplies of different resources.

Changes within the types of grass species present for the three years evaluated, indicated that among the grasses found, only Lolium perenne L. and Poa pratensis L. significantly increased their presence over time (Table 3), independently of the treatments applied (Figure 1). With respect to the other species only the presence of Cardus tenuiflorus Curt. was significant over time.

The multiple correspondence analysis (MCA), carried out to characterize the presence or absence of species according to the seasons and treatments, determined that planting $D$. glomerata did not influence the presence of the grasses identified. Species such as $P$. pratensis, $V$. bromoides and $L$. perenne grew independently of the presence of $D$. glomerata and the treatments applied (Figure 1).

During the experimental period some grass species significantly increased their presence over time (Table 3), specifically Lolium perenne L. and Poa pratensis L. regardless of the treatments applied (Figure 1). In contrast, other species, with the exception of Carduus tenuiflorus Curt., did not exhibit significant changes. Furthermore, there were no sampling effects, which may help to partially explain the amount of total biomass (Huston, 1997). This effect predicts that the total biomass was determined by the increase of probability which comprise a particular species in a community. Species that were dominant in natural 
Table 3. Presence of plant species for the three years according to different treatments.

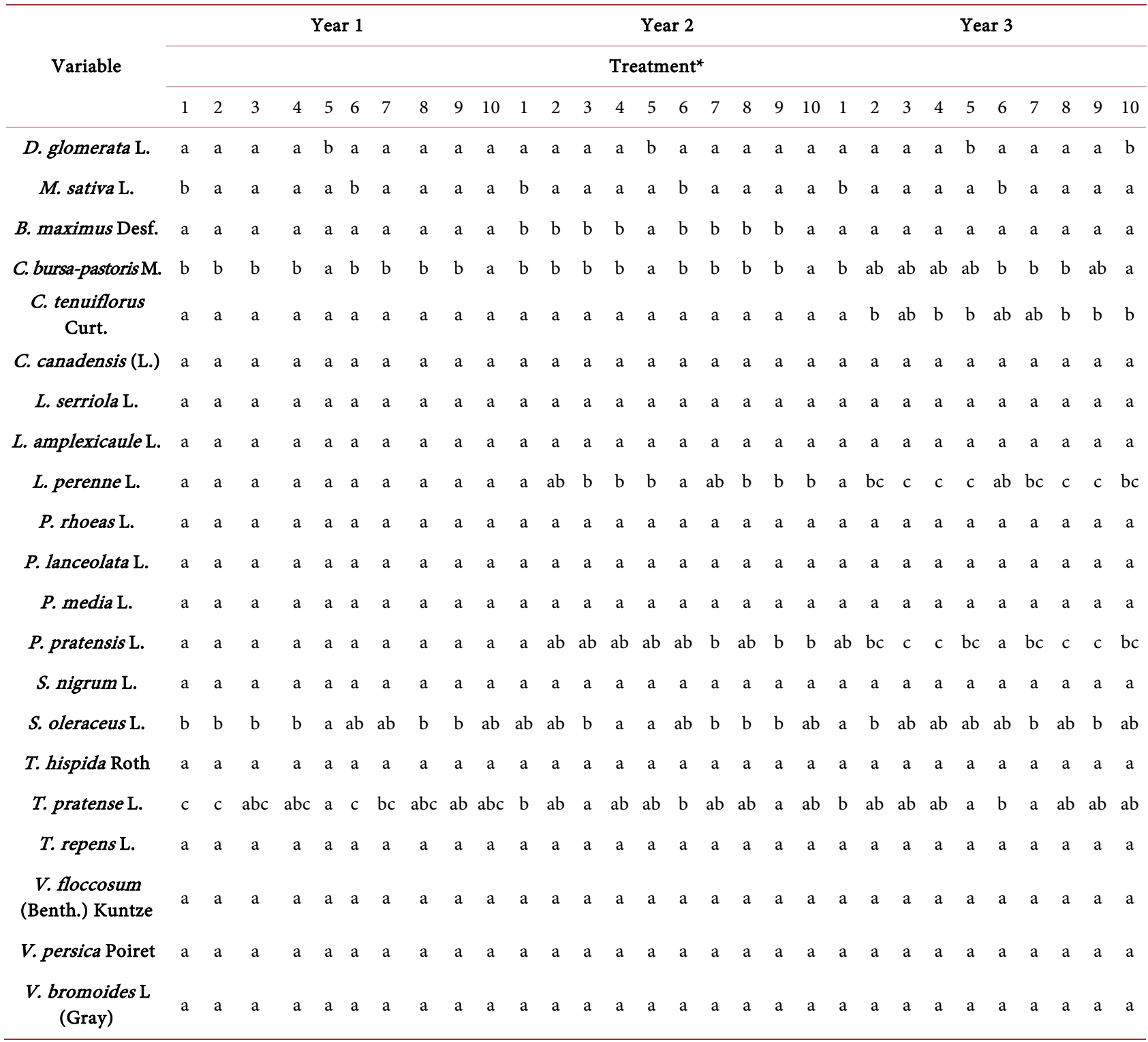

${ }^{*}$ Treatment: 1 = D. glomerata-without phosphorus (P). 2 = D. glomerata: M. Sativa (75:25)—without P. $3=$ D. glomerata: M. Sativa (50:50)—without P. 4 = D. glomerata: M. Sativa (25:75) -without P. $5=$ M. Sativa一without P. $6=$ D. glomerata-with P. $7=$ D. glomerata: M. Sativa (75:25) 一with P. $8=D$. glomerata: M. Sativa (50:50)—with P. 9 = D. glomerata: M. Sativa (25:75) —with P. $10=$ M. Sativa-with P.

conditions were remove from the sown species Lolium perenne was the dominant species, whereas the group of "other forbs" made up most of the dominant species one year after the experimental plots were established. Cardus tenuiflorus was the only species that was positively influenced by the soil seed bank. Similar to the experiment of Lepš et al. (2001), our results support the hypothesis that plant species diversity may have idiosyncratic effects on soil communities, even though long-term studies may reveal time lags in response to changes in the plant composition. Also, the improvement of these communities depends on the stronger competing species (Clarke et al., 2005).

Some arable weed species are considered rare and endangered, and their sur- 
vival is usually dependent on regular ploughing. Some of the arable weeds are highly undesirable (e.g. Cardus teniuflorus), and some species, present in arable field seed bank or those invading the arable field spontaneously from adjacent communities, are also commonly found within meadow communities. The use of $D$. glomerata suppressed annual noxious grasses and increased the control of the group of other-forbs. Although these species are also noxious weeds, they may be substituted with other perennial species of the same functional group throughout the whole experimental period, similar to what had occurred with the other-forb perennial C. tenuifolius, which was the strong dominant present at the end of experimental period in all of the sown and unsown plots.

Bekker et al. (1997) argued that the first plant species to become established within abandoned arable land are weedy species that are already present in the soil seed bank. These plants are opportunists with relatively poor root exploitation capacity. After the initial stage of land abandonment, the initial colonizing plant species are replaced by persistent perennials (Hansson \& Hagelfors, 1998; Kosola \& Gross, 1999). The presence of a strong competitor in a mixture not only suppresses the colonizers, but also leads to reduced survival of the other species sown.

The multiple correspondence analysis (MCA), for the legumes species found showed that planting lucerne (Medicago sativa) did not influence the presence of other legume species that appeared over time (Figure 2).

By using multiple correspondence analysis (MCA) we found that planting $D$. glomerata did not determine the presence of grasses. Species such as $P$. pratensis, $V$. bromoides and $L$. perenne grew independently of the presence of $D$. glomerata and the treatments applied (Figure 1). Another study indicated that there is a weak relationship between native and planted species (Bennett et al., 2012). In the same way, planting lucerne (Medicago sativa) did not influence the presence of other legume species that appeared over time (Figure 2).

The analysis performed for the other species (other than grasses and legumes) also showed that $\mathrm{T} 1$ and $\mathrm{T} 5$ sowing treatments (corresponding to single species without phosphorus application) influenced the presence of $70 \%$ of other species (Figure 3).

The treatments corresponding to single species without phosphorus application (T1 and $\mathrm{T} 5$ treatments) allowed us to determine their influence on the presence of $70 \%$ of the other types of species, such as Carduus tenuiflorus, Lactuca serriola, Conyza canadensis and Sonchus oleraceus, and their perennial life cycle (Figure 3). Another study showed that the specific composition of the communities and the presence of one particular functional group, such as legumes, had significant effects in the biomass production and also in nitrogen accumulation; therefore, legumes contributed to biodiversity and productivity depending on the species present and environmental conditions, such as nutrient availability (Spehn et al., 2002).

The biomass of the different groups changed over time during the three sea- 
sons evaluated, and decreased during the autumn and spring (Figure 4). The legume biomass had a similar pattern (Figure 5). However, there was an increase during the summer season. Variations in the growth of different species could be due to a complex mix of concordant and discordant responses to environmental factors over time (Bennett et al., 2012).

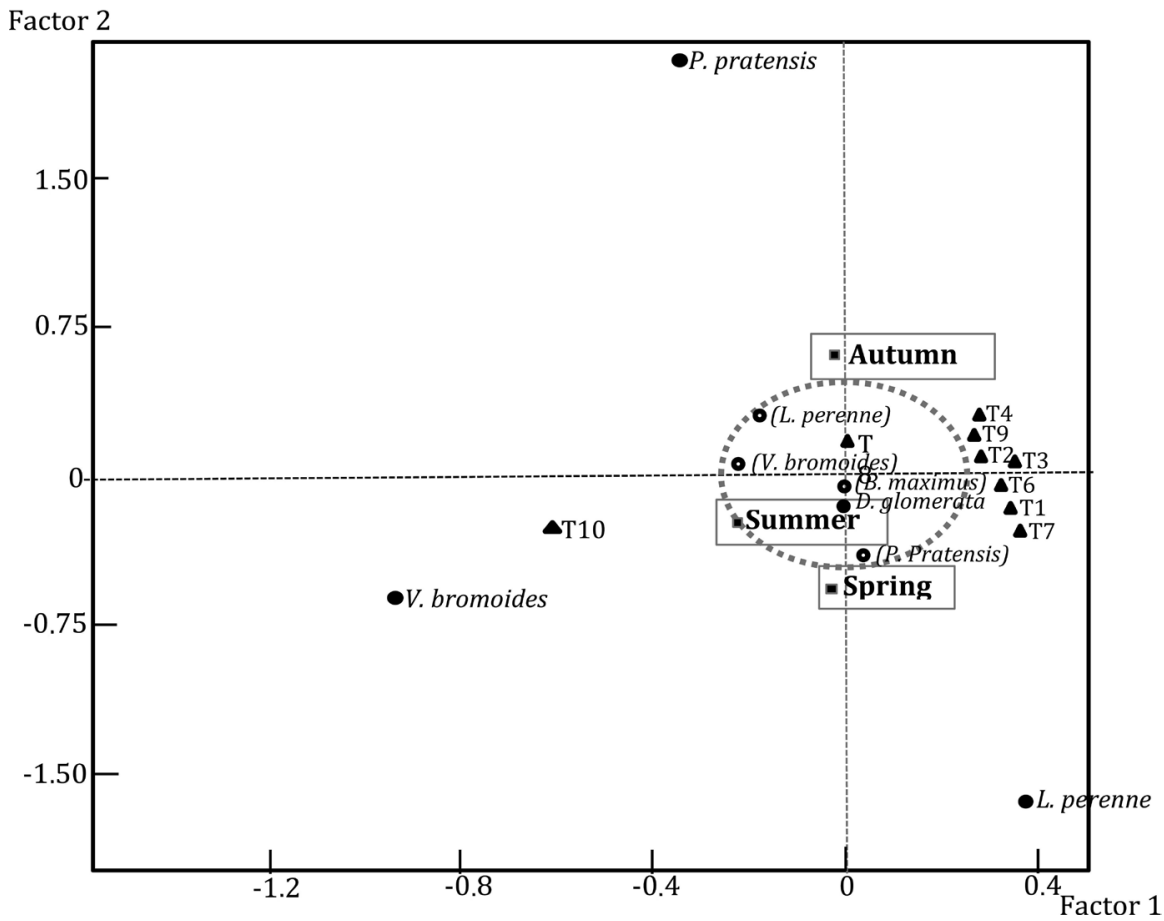

Figure 1. Factorial correspondence analysis of the presence or absence of grasses species (Conventions: - Season $\bullet$ Presence of the species $\circ$ Absence of the species).

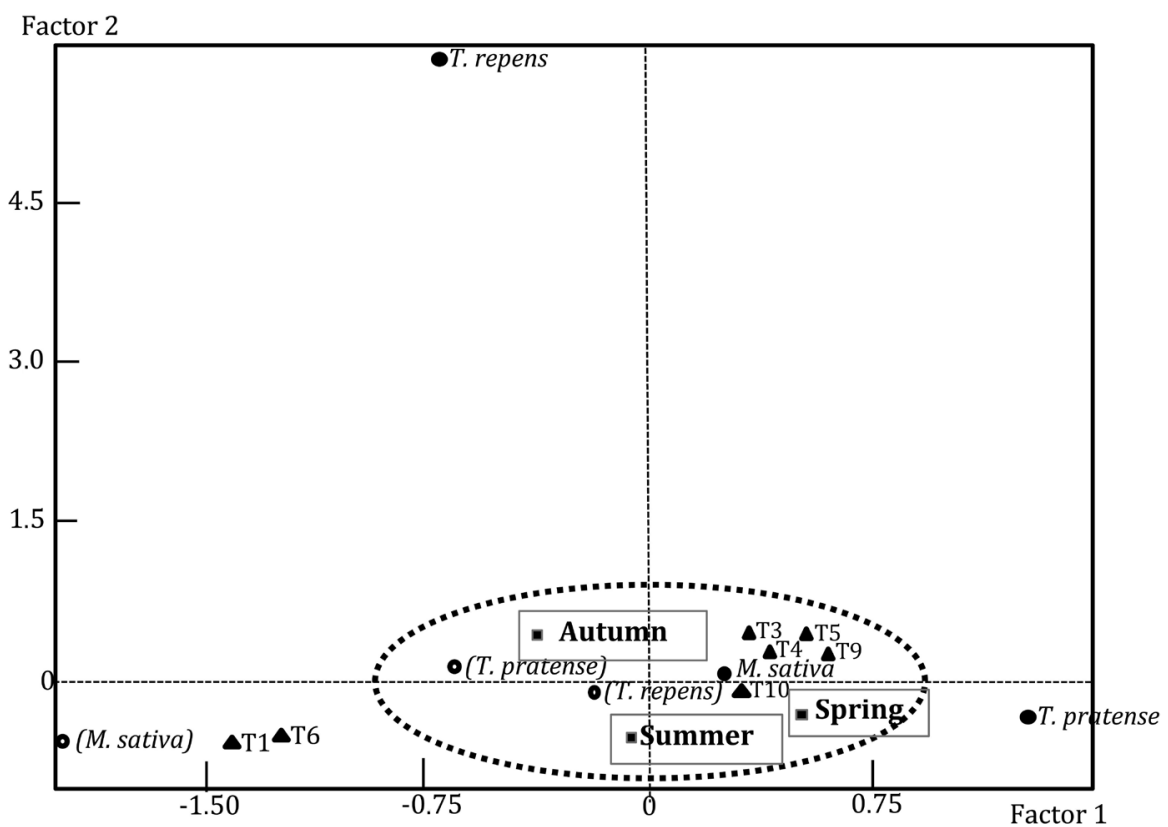

Figure 2. Factorial correspondence analysis of the presence or absence of the legume found species. 


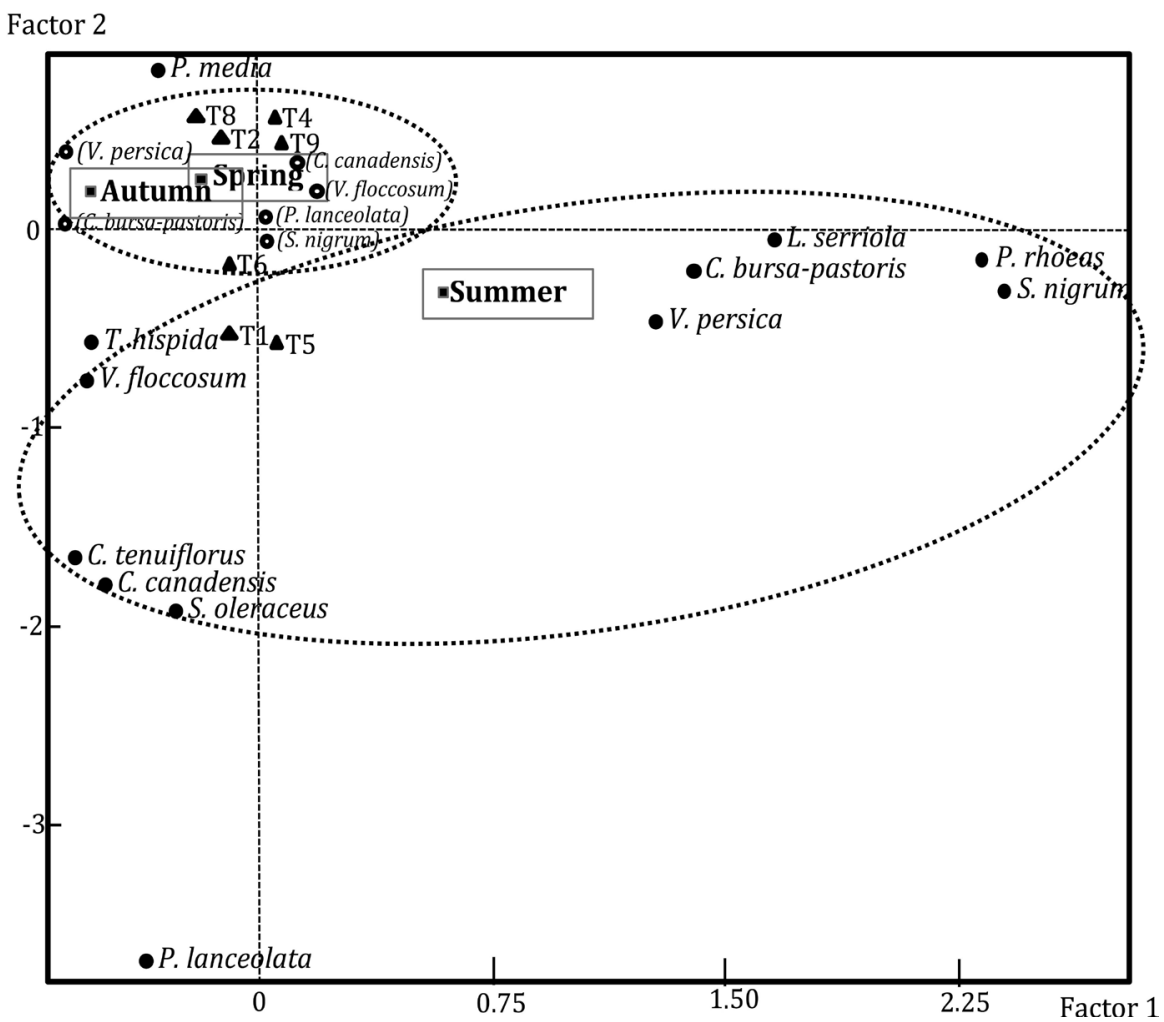

Figure 3. Factorial correspondence analysis of the presence or absence of the other found species.

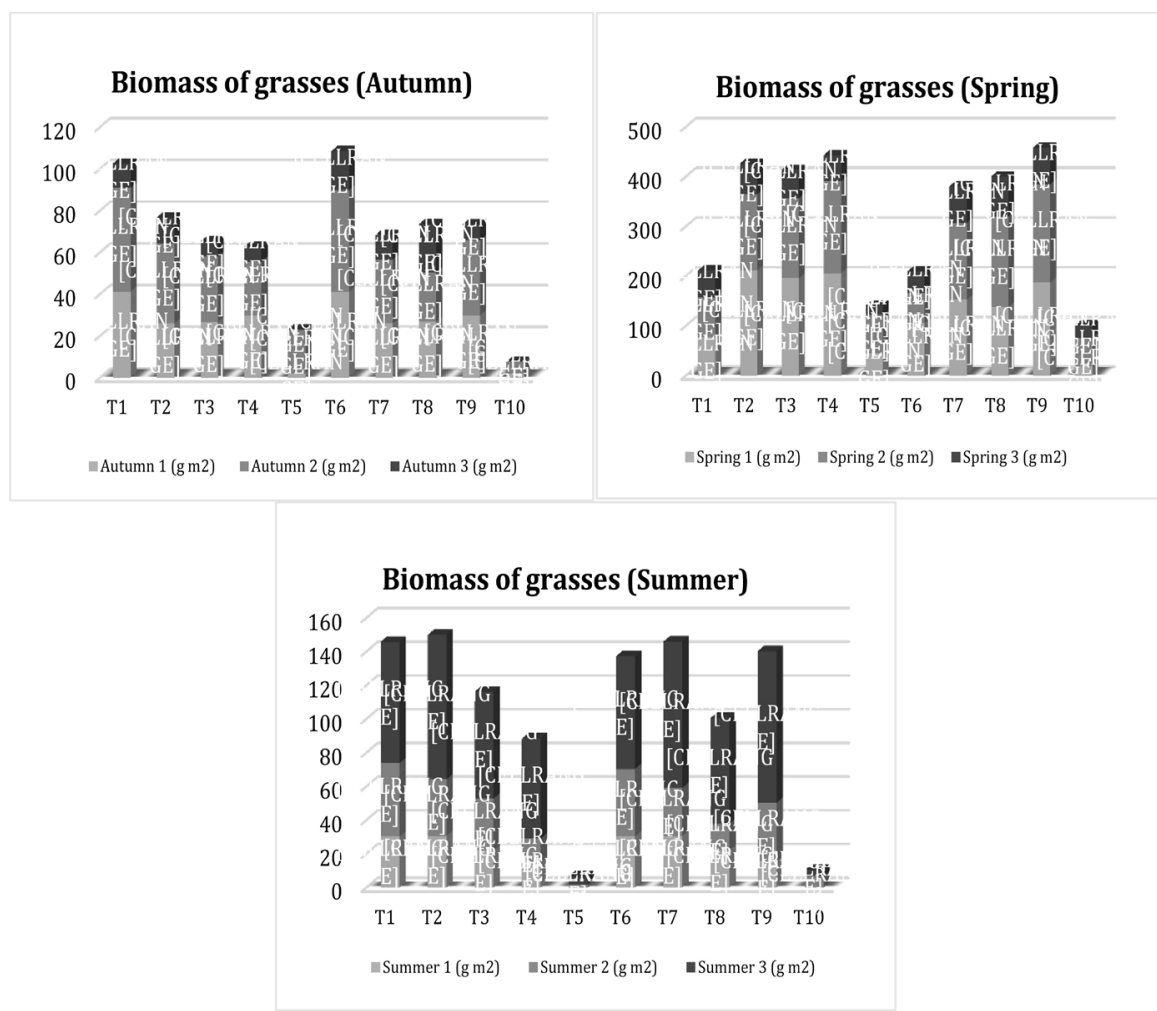

Figure 4. Biomass of grasses from different treatments according to the season. Vertical letters indicate significant difference $(P<0.05)$. 


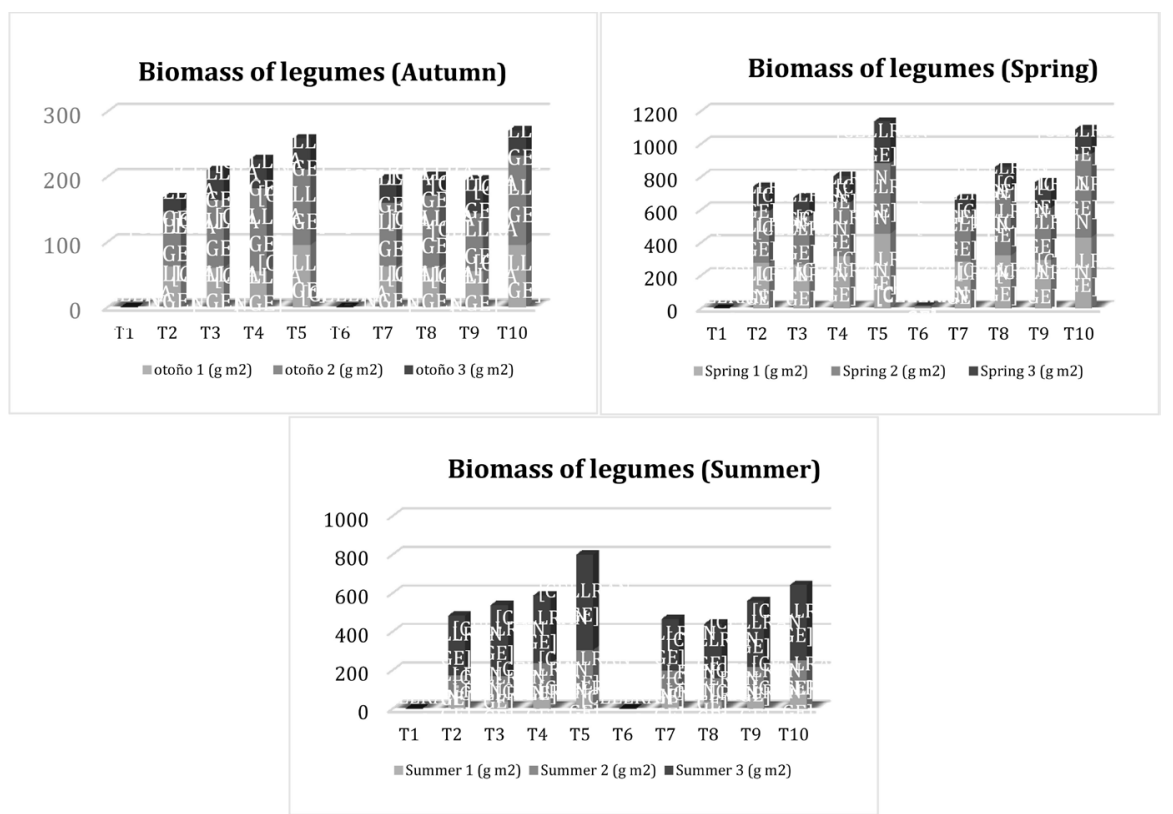

Figure 5. Biomass of legumes from different treatments according to the season. Vertical letters indicate significant difference $(P<0.05)$.

\section{Conclusion}

In this experiment, the result of the aboveground biomass showed a similar pattern between the sowing treatments and natural colonization, therefore the treatment-year interaction was not significant. However, the biomass of different groups changed over time during the three seasons and years evaluated. It was observed that the biomass of grasses decreased significantly during autumn and spring (Figure 4), where the biomass of legumes also showed a similar pattern (Figure 5). Both figures show an increase in biomass during the summer season.

The establishment of Medicago sativa and Dactylis glomerata independently influenced the presence of some perennial species. Local conditions and species identities affect the suppressive capacity of plant communities towards other species, which complicates the generalization of any relationship between the diversity of communities and their susceptibility to invasions. This issue is one of the most critical factors that should be taken into account when planning future restorations of areas such as woodlands, as there is no guarantee that late successional plant species will remain in the areas in which they are planted. The loss of dominance of the species sown due to inappropriate management is quite likely and will inevitably lead to the convergence of species composition with the proliferation of noxious annual weeds.

The use of Medicago sativa and Dactylis glomerata suppresses annual noxious grasses and increases the control of the "other forb" group. Although these species are also noxious weeds, they may be replaced by other perennial species of the same functional group throughout the whole experimental period, similar to what occurred with the other forb perennial $C$. tenuiflorus, which is appeared as a strong dominant at the end of the experimental period in all of the sown and 
unsown plots.

Changes regarding the presence of grass species for the three years evaluated indicated that only Lolium perenne L. and Poa pratensis L. significantly increased their presence over time. However, these changes did not depend on the treatments applied.

\section{Acknowledgements}

COLCIENCIAS and Universidad de Antioquia (Colombia) fellowship to M. Medina-Sierra supported this work and GRICA Sustainability Project 2016-2017.

\section{References}

Bakker, J. P., \& Berendse, F. (1999). Constraints in the Restoration of Ecological Diversity in Grassland and Heathland Communities. Trends in Ecology \& Evolution, 14, 63-68. https://doi.org/10.1016/S0169-5347(98)01544-4

Bekker, R. M., Bakker, J. P., \& Thompson, K. (1997). Dispersal of Plant Species in Time and Space: Can Nature Development Rely on soil Seed Banks and Dispersal? In A. Cooper, \& J. Power (Eds.), Species Dispersal and Land Use Processes, 6th IALE Conference (pp. 247-255). Groningen: University of Groningen.

Bennett, J. R., Dunwiddie, P. W., Giblin, D. E., \& Arcese, P. (2012). Native versus Exotic Community Patterns across Three Scales: Roles of Competition, Environment and Incomplete Invasion. Perspectives in Plant Ecology, Evolution and Systematics, 14, 381-392. https://doi.org/10.1016/j.ppees.2012.10.001

Blanco, A., Forteza, J., Rico, M., \& Sánchez Rodríguez, J. A. (1989). Estudios de la finca experimental "Muñovela" (IRNA/CSIC, Salamanca). In Anuario del Instituto de Recursos Naturales y Agrobiología de Salamanca, XIV (pp. 150-189).

Chapin III, F. S., Zavaleta, E. S., Eviner, V. T., Naylor, R. L., Vitousek, P. M., Reynolds, H. L., Hooper, D. U., Lavore, 1. S., Sala, O. E., Hobbie, S. E., Mack, M. C., \& Diaz, S. (2000). Consequences of Changing Biodiversity. Nature, 405, 234-242. https://doi.org/10.1038/35012241

Clarke, P. J., Latz, P. K., \& Albrecht, D. E. (2005). Long-Term Changes in Semi-Arid Vegetation: Invasion of an Exotic Perennial Grass Has Larger Effects than Rainfall Variability. Journal of Vegetation Science, 16, 237-248.

https://doi.org/10.1111/j.1654-1103.2005.tb02361.x

Crawley, M. (1990). The Population Dynamics of Plants. Philosophical Transactions of the Royal Society B, 330, 125-140. https://doi.org/10.1098/rstb.1990.0187

Foster, B. L., \& Gross, K. L. (1998). Species Richness in a successional Grassland: Effects of Nitrogen Enrichment and Plant Litter. Ecology, 79, 2593-2602. https://doi.org/10.1890/0012-9658(1998)079[2593:SRIASG]2.0.CO;2

Garnier, E., Navas, M. L., Austin, M. P., Lilley, J. M., \& Gifford, R. M. (1997). A Problem for Biodiversity-Productivity Studies: How to Compare the Productivity of Multispecific Plant Mixtures to That of Monocultures? Acta Oecologica, 18, 657-670. https://doi.org/10.1016/S1146-609X(97)80049-5

Gleeson, S.K., \& Tilman, D. (1990). Allocation and the Transient Dynamics of Succession on Poor Soils. Ecology, 71, 1144-1155. https://doi.org/10.2307/1937382

Hansson, M., \& Hagelfors, H. (1998). Management of Permanent Set-Aside on Arable Land in Sweden. Journal of Applied Ecology, 35, 758-771.

https://doi.org/10.1046/j.1365-2664.1998.355350.x 
Hector, A., Schmid, B., Beierkuhnlein, C., Caldeira, M. C., Diemer, M., Dimitrakopoulos, P. G., Finn, J. A., Freitas, H., Giller, P. S., Good, J. Harris, R., Hogberg, P., Huss-Danell, K., Joshi, J., Jumpponen, A., Korner, C., Leadley, P. W., Loreau, M., Minns, A., Mulder, C. P. H., O’Donovan, G., Otway, S. J., Pereira, J. S., Prinz, A., Read, D. J., Scherer-Lorenzen, M., Schulze, E. D., Siamantziouras, A. S. D., Spehn, E. M., Terry, A. C., Troumbis, A. Y., Woodward, F. I., Yachi, S., \& Lawton, J. H. (1999). Plant Diversity and Productivity Experiments in European Grasslands. Science, 286, 1123-1127. https://doi.org/10.1126/science.286.5442.1123

Hedlund, K., Santa-Regina, I., Van der Putten, W. H., Leps, J., Diaz, T. A., Korthals, G. H., Lavorel, S., Brown, V. K., Gormsen, D., Mortimer, S. R., Rodriguez-Barrueco, C., Roy, J., Šmilauer, P., Šmilauerová, M., \& van Dijk, C. (2003). Plant Species Diversity, Plant Biomass and Responses of the Soil Community on Abandoned Land across Europe: Idiosyncracy or Above-Belowground Time Lags. Oikos, 103, 45-58. https://doi.org/10.1034/j.1600-0706.2003.12511.x

Henkin, Z., Sternberg, M., No’am, G. S., \& Noy-Meir, I. (2006). Species Richness in Relation to Phosphorus and Competition in a Mediterranean Dwarf-Shrub ty. [Agriculture Ecosystems \& Environment, 113, 277-283.

Henkin, Z., Seligman, N. G., Noy-Meir, I., Kafkafi, U., \& Gutman, M. (1998). Rehabilitation of Mediterranean Dwarf-Shrub Rangeland with Herbicides, Fertilizer and Fire. Journal of Range Management, 51, 193-199. https://doi.org/10.2307/4003207

Hooper, D. U. (1998). The Role of Complementarity and Competition in Ecosystem Responses to Variation in Plant Diversity. Ecology, 79, 704-719. https://doi.org/10.1890/0012-9658(1998)079[0704:TROCAC]2.0.CO;2

Hooper, D. U., \& Vitousek, P. M. (1997). The Effect of Plant Composition and Diversity on Ecosystem Processes. Science, 277, 1302-1304. https://doi.org/10.1126/science.277.5330.1302

Huston, M. A. (1997). Hidden Treatments in Ecological Experiments: Re-Evaluating the Ecosystem Function of Biodiversity. Oecologia, 110, 449-460.

https://doi.org/10.1007/s004420050180

Janssens, F., Peeters, A., Tallowin, J. R. B., Bakker, J. P., Bekker, R. M., Fillat, F., \& Oomes, M. J. M. (1998). Relationship between Soil Chemical Factors and Grassland Diversity. Plant and Soil, 202, 69-78. https://doi.org/10.1023/A:1004389614865

Keane, R. M., \& Crawley, M. J. (2002). Exotic Plant Invasions and the Enemy Release Hypothesis. Trends in Ecology \& Evolution, 17, 164-169.

Knops, J. M. H., \& Tilman, D. (2000). Dynamics of Soil Nitrogen and Carbon Accumulation for 61 Years after Agricultural Abandonment. Ecology, 81, 88-98. https://doi.org/10.1890/0012-9658(2000)081[0088:DOSNAC]2.0.CO;2

Kosola, K. R., \& Gross, K. L. (1999). Resource Competition and Suppression of Plants Colonizing Early Successional Old Fields. Oecologia, 118, 69-75. https://doi.org/10.1007/s004420050704

Lanta, V., \& Lepš, J. (2006). Effect of Functional Group Richness and Species Richness in Manipulated Productivity-Diversity Studies: A Glasshouse Pot Experiment. Acta Oecologica, 29, 85-96.

Lepš, J., Brown, V., Diaz, T. A., Gormsen, D., Hedlund, K., Kailova, J., Korthals, G. H., Mortimer, S. R., Rodriguez-Barrueco, C., Roy, J., Santa-Regina, I., van Dijk, C., \& van der Putten, W. H. (2001). Separating the Chance Effect from Other Diversity Effects in the Functioning of Plant Communities. Oikos, 92, 123-134. https://doi.org/10.1034/j.1600-0706.2001.920115.x

Nijs, I., \& Roy, J. (2000). How Important Are Species Richness, Species Evenness and In- 
terspecific Differences to Productivity? A Mathematical Model. Oikos, 88, 57-66. https://doi.org/10.1034/j.1600-0706.2000.880107.x

Oliveira, L. B., Soares, E. M., Jochims, F., Tiecher, T., Marques, A. R., Kuinchtner, B. C., \& de Quadros, F. L. (2015). Long-Term Effects of Phosphorus on Dynamics of an Over-Seeded Natural Grassland in Brazil. Rangeland Ecology \& Management 68, 445452.

Osbornová, J., Kovárová, M., Lepš, J., \& Prach, K. (1990). Succession in Abandoned Fields. Studies in Central Bohemia (169 p.). Dordrecht: Czeckoslovakia. Kluwer Academic Publishers.

Osman, A. E., Cocks, P. S., Russi, L., \& Pagnotta, M. A. (1991). Response of Mediterranean Grassland to Phosphate and Stocking Rates: Biomass Production and Botanical Composition. Journal of Agricultural Science, 116, 37-46. https://doi.org/10.1017/S0021859600076127

Osman, A. E., Salkini, A. K., \& Ghassali, F. (1999). Productivity and Botanical Composition of Mediterranean Grassland in Relation to Residual Phosphate. Journal of Agricultural Science, 132, 399-405. https://doi.org/10.1017/S0021859699006462

Richards, J. F. (1990). Land Transformation. In B. L. Turner II, W. C. Clark, R. W. Kates, J. F. Richards, J. T. Mathews, \& W. B. Meyer (Eds.), The Earth as Transformed by Human Action (pp. 163-178). Cambridge: Cambridge University Press.

Roy, J. (2001). How Does Biodiversity Control Primary Productivity? In H. A. Mooney, B. Saugier, \& J. Roy (Eds.), Global Terrestrial Productivity: Past, Present and Future (pp. 169-186). San Diego: Academic Press.

Schläpfer, F., \& Schmid, B. (1999). Ecosystem Effects of Biodiversity: A Classification of Hypotheses and Exploration of Empirical Results. Ecological Applications, 9, 893-912. https://doi.org/10.1890/1051-0761(1999)009[0893:EEOBAC]2.0.CO;2

Seligman, N. G. (1996). Management of Mediterranean Grasslands. In J. Hodgson, \& A W. Illius (Eds.), The Ecology and Management of Grazing Systems (pp. 359-392). Wallingford: CAB International.

Spehn, E. M., Scher-Lorensen, M., Schmid, B., Hector, A., Caldiera, M. C., Dimitrakopoulos, P. G., Finn, J. A., Jumpponen, A., O’Donnovan, G., Pereira, J. S., Schulze, E.-D., Troumbis, A. Y., \& Korner, C. (2002). The Role of Legumes as a Component of Biodiversity in a Cross-European Study of Grassland Biomass Nitrogen. Oikos, 98, 205-218. https://doi.org/10.1034/j.1600-0706.2002.980203.x

Teixeira, R. F., Proença, V., Crespo, D., Valada, T., \& Domingos, T. (2015). A Conceptual Framework for the Analysis of Engineered Bio-Diverse Pastures. Ecological Engineering, 77, 85-97.

Tilman, D. (1982). Resource Competition and Community Structure. Princeton, NJ: Princeton University Press.

Tilman, D. (1999). The Ecological Consequences of Changes in Biodiversity: A Search for General Principles. Ecology, 80, 1455-1474. https://doi.org/10.2307/176540

Tilman, D., Knop,s J., Wedin, D., Reich, P., Ritchie, M., \& Sieman, E. (1997). The Influence of Functional Diversity and Composition on Ecosystem Processes. Science, 277, 1300-1302. https://doi.org/10.1126/science.277.5330.1300

Tilman, D., \& Pacala, S. (1993). The Maintenance of Species Richness in Plant Communities. In R. E. Ricklefs, \& D. Schluter (Eds.), Species Diversity in Ecological Communities: Historical and Geographical Perspectives (pp. 13-25). Chicago, IL: University of Chicago Press. 
Tilman, D., Wedin, D., \& Knops, J. (1996). Productivity and Sustainability Influenced by Biodiversity in Grassland Ecosystems. Nature, 379, 718-720. https://doi.org/10.1038/379718a0

van Ruijven, J., \& Berendse, F. (2005). Diversity-Productivity Relationships: Initial Effects, Long-Term Patterns, and Underlying Mechanisms. Proceeding of the National Academic of Science of the United States of America, 102, 695-700. https://doi.org/10.1073/pnas.0407524102

Vilà, M., \& Weiner, J. (2004). Are Invasive Plant Species Better Competitors than Native Plant Species?_Evidence from Pair-Wise Experiments. Oikos, 105, 229-238. https://doi.org/10.1111/j.0030-1299.2004.12682.x

Wardle, D. A. (2001). Experimental Demonstration That Plant Diversity Reduces Invisibility: Evidence of a Biological Mechanism or a Consequence of Sampling Effect? Oikos, 95, 161-170. https://doi.org/10.1034/j.1600-0706.2001.950119.x

Wardle, D. A., Bonner, K. I., Barker, G. M., Yeates, G. W., Nicholson, K. S., Bardgett, R. D., Watson, R. N., \& Ghani, A. (1999). Plant Removals in Perennial Grassland: Vegetation Dynamics, Decomposers, Soil Biodiversity, and Ecosystem Properties. Ecological Monographs, 69, 535-568. https://doi.org/10.1890/0012-9615(1999)069[0535:PRIPGV]2.0.CO;2

Wardle, D. A., \& Zackrisson, O. (2005). Effects of Species and Functional Group Loss on Island Ecosystem Properties. Nature, 435, 806-810.

https://doi.org/10.1038/nature03611

Williamson, M. (1996). Biological Invasions. London: Chapman and Hall.

\section{Submit or recommend next manuscript to SCIRP and we will provide best} service for you:

Accepting pre-submission inquiries through Email, Facebook, LinkedIn, Twitter, etc. A wide selection of journals (inclusive of 9 subjects, more than 200 journals).

Providing 24-hour high-quality service

User-friendly online submission system

Fair and swift peer-review system

Efficient typesetting and proofreading procedure

Display of the result of downloads and visits, as well as the number of cited articles

Maximum dissemination of your research work

Submit your manuscript at: http://papersubmission.scirp.org/

Or contact ojf@scirp.org 